\title{
Modelling dominant height growth and site index curves for rebollo oak (Quercus pyrenaica Willd.)
}

\author{
Patricia ADAME $^{\mathrm{a} *}$, Isabel CAÑELLAS ${ }^{\mathrm{b}}$, Sonia RoIG $^{\mathrm{b}}$, Miren DEL Río $^{\mathrm{b}}$ \\ ${ }^{a}$ Departamento de Investigación y Experiencias Forestales de Valonsadero, Junta de Castilla y León, Aptdo 175, Soria 42080, Spain \\ ${ }^{\mathrm{b}}$ Forest Research Centre (CIFOR-INIA), Ctra A Coruña km 7,5, Madrid 28040, Spain
}

(Received 18 July 2005; accepted 9 May 2006)

\begin{abstract}
A dominant height growth model and a site index model were developed for rebollo oak (Quercus pyrenaica Willd.) in northwest Spain. Data from 147 stem analysis in 90 permanent plots, where rebollo oak was the main species, were used for modelling. The plots were selected from the National Forest Inventory at random in proportion to four biogeoclimatic stratums. Different traditional and generalized algebraic difference equations were tested. The evaluation criteria included qualitative and quantitative examinations and a testing with independent data from another region. The generalized algebraic difference equation of Cieszewski based on Bailey equation showed the best results for the four stratums. An analysis of the height growth patterns among ecological stratums was made in order to study the necessity of different site index curves. Results indicated the validity of a common height growth model for the four stratums. In spite of the irregular height growth pattern observed in rebollo oak, probably due to past management, the model obtained allows us to classify and compare correctly rebollo oak stands growing at different sites.
\end{abstract}

growth model / site index / rebollo oak / coppices / algebraic difference equations

Résumé - Modèle de croissance en hauteur et qualité de station de chêne tauzin (Quercus pyrenaica Willd.). Les auteurs ont développé un modèle de croissance pour estimer la hauteur dominante et la qualité de station des peuplements de chêne tauzin (Quercus pyrenaica Willd.) dans le NordOuest de l'Espagne. Les données pour établir ce modèle proviennent d'analyse de tiges de 147 arbres dominants de 24 placettes permanentes où l'espèce est la plus représentée. Ces placettes de l'Inventaire Forestier Espagnol ont été proportionnellement réparties dans quatre régions biogéoclimatiques. Huit équations en différences algébriques et huit équations en différences algébriques généralisées ont été essayées pour développer des courbes de croissance. Des analyses numériques, des analyses graphiques et une validation sur un échantillonnage indépendant ont été utilisées pour comparer les différents modèles existants. La fonction de Cieszewski fondée sur l'équation de Bailey avec la méthode des différences algébriques généralisées a donné les meilleurs résultats dans les quatre régions biogéoclimatiques. Les différences des modèles entre écorégions ont été étudiées afin de déterminer si la construction de quatre modèles régionaux différents était nécessaire. Les résultats indiquent qu'un seul modèle commun est utilisable pour toutes les régions étudiées. Malgré une croissance irrégulière en hauteur dominante du chêne tauzin, probablement à cause des gestions antérieures, le modèle recommandé permet de classer et comparer correctement les peuplements de chêne tauzin qui poussent dans différentes régions.

modèle de croissance en hauteur / qualité de station / chêne tauzin / taillis / différences algébriques généralisées

\section{INTRODUCTION}

The species Quercus pyrenaica Willd. is widely extended in the Iberian Peninsula [21] (Fig. 1), although its natural area covers a large proportion of Western France and there are enclaves in the Rif mountains of Morocco. The species seems to be transitional between genuine oaks (Quercus robur L. and Q. petraea (Matt.) Liebl.) and other Quercus species better adapted to the long, dry summers characteristic of Mediterranean climates, although its physionomy is clearly closer to that of the former. In general terms, the species establishes itself on siliceous ground, from continental to subhumid and humid climates, and altitude ranks of (400) 800-1200 (1600) $\mathrm{m}[14,21]$. The most significant stands are located in the mountain ranges in the north-western part of the Iberian Peninsula.

\footnotetext{
* Corresponding author: adaherpa@jcyl.es,

Pat-adame@hotmail.com
}

The Second National Forest Inventory of Spain (1985$1995)$ shows that the coppice areas of $Q$. pyrenaica represent $64 \%$ of the total area for the species which is 659000 ha [23]. Management of these coppices is one of the biggest problems that forestry research is facing in Spain. For the last 50 years at least, it might be assumed that the average rotation length for Mediterranean coppices in Spain has varied between 20 and 30 years as a consequence of variations in the economy and the sociology of rural areas. This treatment was progressively abandoned due to the decrease in use of firewood and charcoal as an energy source and to rural emigration to the cities. As a result of this lack of management, these stands now suffer severe ecological, economic and social constraints, which may endanger the existence of these stands in the long term.

In Spain, 50\% of the total surface area of this Mediterranean oak can be found in the region of Castilla y Leon (Fig. 1). Owing to its large extension, this community contains areas with different biogeoclimatic characteristics. According 


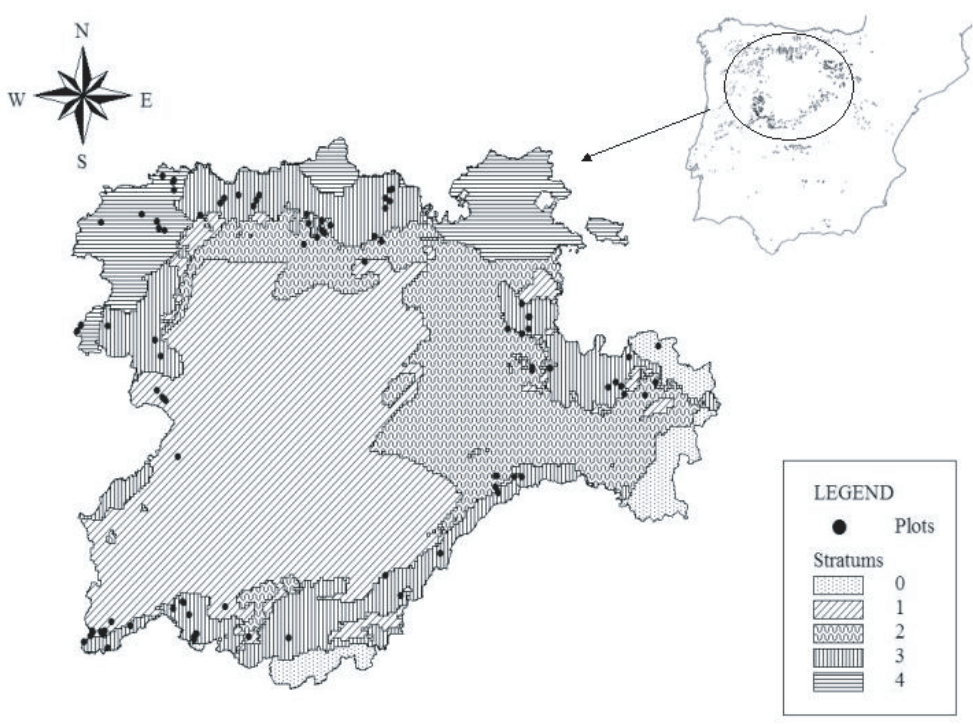

Figure 1. Distribution of the range of Quercus pyrenaica Willd. in Iberian Peninsule [21], biogeoclimatic stratums in Castilla-León [25] and sample plots.

to Elena Rosselló [25], the region is covered by two main ecorregions. Ecorregion 1, situated in the north, has an Atlantic climate with high precipitation and mild average temperature. Whereas, the ecorregion 2, which occupies the centre and the south, is a Mediterranean climate with less precipitation and extreme temperatures. The second of these two ecorregions can be classified into different stratums according to altitude.

The recognition of these problems in such wide areas, and the increasing interest in using these stands for either direct production (such as wine barrels) or indirect production (such as silvopastoral uses, recreation, environmental preservation) justifies the urgent need to guarantee a sustainable management of rebollo oak stands [10]. Considering the high environmental and silvicultural variability of these stands, it is necessary to typify and characterize them in order to optimise their management.

Estimating forest productivity is both necessary for effective forest management and useful for evaluating basic site conditions for ecological field studies. Site quality is therefore influenced by factors such as available light, heat, moisture, and nutrients, along with other soil characteristics such as soil depth and aeration [49]. Although it would be best to directly measure and predict these factors, some of them fluctuate widely over the course of a day, month or year, whereas others require precise measurements that may be difficult to extrapolate across scales. Therefore, indirect methods for evaluating site quality are more frequently used in forest management $[9,37,39]$.

Site index, defined as dominant height at some fixed base age, is one of the most commonly used indicators of site productivity because there exists a close correlation between volume and dominant height growth, and it is generally accepted that height of dominant trees, oak species $[24,43,47]$ included, is only slightly affected by competition. Many mathematical functions are available to model dominant height growth. Desirable characteristics for growth functions are $[5,6,18,26]$ : polymorphism, existence of inflection point and horizontal asymptote, logical behaviour, right theoretical basis, base-age invariance, and parsimony. These requirements are achieved depends on both the construction method and the mathematical function used to develop the curves. Among the three general methods for site index curve construction [19] the algebraic difference approach (ADA) presents the advantages [17, 18, 26]: short observations periods can be effectively used and the structure of equations is base-age invariant. On the other hand the generalized algebraic difference approach (GADA) improves the traditional algebraic difference approach (ADA) allowing more flexible dynamic equations which can be polymorphic and with multiple asymptotes [15].

Modelling dominant height growth for $Q$. pyrenaica in the Mediterranean region has received little attention. Bengoa [7] developed site index curves for $Q$. pyrenaica in La Rioja, and Torre [48] established them in León. Both used the Richards function to fit the model and the mean total age of the stem analysis was around 30 years. This age could be enough for traditional management in which rotations between 20 and 30 years are used, but it is insufficient for the current situation of these coppices. Carvalho [12,13] studied dominant height growth in Continental Portugal using a generalized algebraic difference equation of the Chapman-Richards function in the analysis of 120 years old stems.

The main goal of this study was to develop a dominant height growth model for $Q$. pyrenaica growing in four different biogeoclimatic stratums in northwest Spain, which would serve as a base for a site quality model based on environmental factors. To realize this objective, the variability in dominant height growth patterns and the differences among the stratums were analysed. 
Table I. Characteristics of the stratums.

\begin{tabular}{lccccc}
\hline Ecorregion & Stratum & Area $\left(\mathrm{km}^{2}\right)$ & Tm $\left({ }^{\circ} \mathrm{C}\right)$ & Ppm $(\mathrm{mm})$ & Altm $(\mathrm{m})$ \\
\hline 2 & 1 & 40505 & 11.7 & 517 & 818 \\
2 & 2 & 22157 & 10.5 & 600 & 939 \\
2 & 3 & 17566 & 9.2 & 905 & 1245 \\
1 & 4 & 10074 & 10.4 & 1241 & 904 \\
\hline
\end{tabular}

Tm: mean temperature; Ppm: mean precipitation; Altm: mean altitude.

Table II. Summary of statistics and distribution of stem analysis sample trees per stratum.

\begin{tabular}{lccccccc}
\hline Stratum & Total & Mean $T$ & SD $T$ & $T$ min-max & Mean $H_{0}$ & SD $H_{0}$ & $H_{0}$ min-max \\
\hline 1 & 27 & 69.7 & 25.13 & $41-135$ & 11 & 2.67 & $5.85-16.01$ \\
2 & 35 & 60.7 & 27.28 & $29-158$ & 9.06 & 3.03 & $4.4-16.35$ \\
3 & 80 & 58.7 & 21.81 & $26-119$ & 10.06 & 2.86 & $3.3-16.95$ \\
4 & 17 & 55.4 & 22.75 & $23-87$ & 9.81 & 2.41 & $5.53-14.85$ \\
Total & 159 & 60.67 & 23.87 & $23-158$ & 9.97 & 2.85 & $3.3-16.95$ \\
\hline
\end{tabular}

$\mathrm{T}=$ age (years); $\mathrm{H}_{0}=$ dominant height $(\mathrm{m}) ; \mathrm{SD}=$ standard deviation; $\min -\mathrm{max}$ = range.

Table III. Summary of statistics for the testing data set.

\begin{tabular}{lccccccc}
\hline Ecorregion & Total & Mean $T$ & SD $T$ & $T$ min-max & Mean $H_{0}$ & SD $H_{0}$ & $H_{0}$ min-max \\
\hline 2 & 63 & 44.3 & 9.85 & $17-60$ & 9.25 & 2.0 & $5.3-14.2$ \\
\hline
\end{tabular}

$\mathrm{T}=$ age (years); $\mathrm{H}_{0}=$ dominant height $(\mathrm{m}) ; \mathrm{SD}=$ standard deviation; $\min -\mathrm{max}=$ range.

\section{MATERIALS AND METHODS}

\subsection{Data set}

The data was obtained from plots which were selected from the third Spanish National Forest Inventory. This consists of a systematic sample of permanent plots distributed on a square grid of $1 \mathrm{~km}$, with a remeasurement interval of 10 years. From inventory plots throughout the whole of the Castilla-León region, 90 plots were selected in which $Q$. pyrenaica was the dominant species (highest basal area proportion). The selection was random but in proportion to the four main stratums defined by Elena Rosselló [25] in this area (Fig. 1). According to this author, two ecorregions and four stratums can be defined in the study area. The stratums 1, 2 and 3 belong to ecorregion 2 . and the last stratum (stratum 4), belongs to ecorregion 1 . The mean characteristics of each stratum are shown in Table I.

One or two trees were chosen as sample trees in the same stand but outside the original plot, so it is avoided to destroy the permanent plot. The sample trees had to be codominant or dominant trees free of damage and without any obvious history of suppression. Each tree selected was felled and the total height was measured. The height-age pairs were determined by making cross-sectional cuts at every meter starting at stump height $(0.30 \mathrm{~m})$. The TSAP software was used with a linear positioning digitiser tablet LINTAB to measure the annual ring count for each disc. Because cross section lengths do not coincide with periodic height growth, it was necessary to adjust height/age data from the stem analysis to compensate this bias using Carmean's method [11] and the modification proposed by Newberry [38] for the topmost section of the tree. The data summary of the sampled stem analysis is presented in Table II.

Individual tree height age curves were then plotted and inspected for signs of early suppression or top damage that may have caused ab- normal tree height growth patterns. Once these trees were eliminated, the data set was composed of 147 stem analyses.

Total age was chosen as the independent variable. Many authors $[11,18,29,37]$ have suggested the use of breast height age, but other authors maintain that this variable ignores the differences in early age caused by different ecological conditions $[9,24,26]$.

Independent data sets from permanent sample plots located in ecorregion 2, in central Spain and on the southern slopes of the Central mountain range (Madrid region), were used to test the performance of the proposed dominant height growth model. Measurements were taken and data collected at these sample plots in 2004 using a procedure similar to that which was used in the modelling data set. Therefore, 63 stem analyses from 38 plots were analysed. The characteristics of sampled stem analysis are shown in Table III.

\subsection{Candidate functions}

Traditional algebraic difference approach (ADA) and generalized algebraic difference approach (GADA) have been used, since they have showed better properties and performance than analogous fixed-base-age equations [15, 17]. A total of sixteen models were selected from those most commonly used in forest research as candidate functions to model dominant height growth (Tab. IV). The first group (Tab. IVa) was formulated based on the heightage equations. They are polymorphic functions derived the two first from the Chapman-Richards function [41] and the third and fourth from the Lundqvist-Korf function [34]. Model 5 was proposed by McDill-Amateis [35], obtained from Hossfeld IV model (cited by Peschel [40]) applying ADA to its parameter $b$. Models 6 to 8 belong to the second group (Tab. IVb) and they were formulated based on the 
Table IV. Candidate models for dominant height modelling: (a) models from height-age equation; (b) models from differential equations; (c) models from Generalized Algebraic Difference Approach (GADA).

(a)

\begin{tabular}{|c|c|c|c|c|}
\hline Name & Height-age equation & Model & $\begin{array}{l}\text { Algebraic difference model from } \\
\text { height-age equations }\end{array}$ & F.p. \\
\hline $\begin{array}{l}\text { Chapman-Richards } \\
\text { (1959) }\end{array}$ & $H=a \cdot\left(1-\exp ^{-b \cdot T}\right)^{\frac{1}{(1-c)}}$ & (1) & $H_{2}=a \cdot\left\{1-\left[1-\left(\frac{H_{1}}{a}\right)^{(1-c)}\right]^{\left(\frac{T_{2}}{T_{1}}\right)}\right\}^{\left(\frac{1}{(1-c)}\right)}$ & $b$ \\
\hline & & (2) & $H_{2}=a^{\left\{1-\left[\frac{\ln \left(1-e^{-c \cdot T_{2}}\right)}{\ln \left(1-e^{-c \cdot T_{1}}\right)}\right]\right\}} \cdot H_{1}^{\left[\frac{\ln \left(1-e^{-c \cdot T_{2}}\right)}{\ln \left(1-e^{-c \cdot T_{1}}\right)}\right]}$ & $c$ \\
\hline \multirow{2}{*}{$\begin{array}{l}\text { Lundqvist-Korf } \\
\text { (1939) }\end{array}$} & $H=a \cdot \exp ^{\frac{b}{t^{c}}}$ & (3) & $H_{2}=a \cdot\left(\frac{H_{1}}{a}\right)^{\left(\frac{T_{1}}{T_{2}}\right)^{c}}$ & $b$ \\
\hline & & (4) & $H_{2}=\frac{a}{\ln T_{1} \sqrt{\ln \frac{T_{2}}{\frac{T_{2}}{2}}}}$ & $c$ \\
\hline $\begin{array}{l}\text { McDill } \\
\text { Amateis } \\
\text { (1992) }\end{array}$ & $\begin{array}{l}H=\frac{a}{1+\frac{b}{T^{c}}} \\
\text { assuming } b=\frac{d}{S}\end{array}$ & (5) & $H_{2}=\frac{a}{1-\left[1-\left(\frac{a}{H_{1}}\right)\right] \cdot\left(\frac{T_{1}}{T_{2}}\right)^{c}}$ & $b$ \\
\hline
\end{tabular}

$H_{i}$ is dominant height $(\mathrm{m})$ at age $T_{i}$ (years); $S=$ Site index; $a, b, c$ and $d$ are fitted parameters of the function. F.p. $=$ free parameter.

(b)

\begin{tabular}{|c|c|c|c|}
\hline Name & Differential equation & Model & $\begin{array}{l}\text { Algebraic difference model } \\
\text { from differential equations }\end{array}$ \\
\hline $\begin{array}{l}\text { Clutter- Lenhart } \\
\text { (1968) }\end{array}$ & $\begin{array}{l}\frac{\mathrm{d} \ln (H)}{\mathrm{d}(1 / T)}=\alpha+\beta \cdot \ln (H)+\delta / T \\
a=-(\alpha+\delta / \beta) ; b=-\delta / \beta ; c=\beta\end{array}$ & (6) & $H_{2}=\mathrm{e}^{\left(\left(a+\frac{b}{T_{2}}+\left(\ln \left(H_{1}\right)-a-\frac{b}{T_{1}}\right)\right) \cdot e^{\left(c \cdot\left(\frac{1}{T_{2}}-\frac{1}{T_{2}}\right)\right)}\right)}$ \\
\hline $\begin{array}{l}\text { Amateis - Burkhart } \\
\text { (1985) }\end{array}$ & $\frac{\mathrm{d} \ln (H)}{\mathrm{d}(1 / T)}=a \cdot \ln (H)+b \cdot \ln (H) \cdot T$ & (7) & $H_{2}=\mathrm{e}^{\left(\ln \left(H_{1}\right) \cdot\left(\frac{T_{1}}{T_{2}}\right)^{b} \cdot e^{\left.a \cdot\left(\frac{1}{T_{2}}-\frac{1}{T_{1}}\right)\right]}\right)}$ \\
\hline $\begin{array}{l}\text { Sloboda } \\
\text { (1971) }\end{array}$ & $\frac{\mathrm{d} H}{\mathrm{~d} T}=\ln \left(\frac{a}{H}\right) \cdot b \cdot\left(\frac{H}{T^{c}}\right)$ & (8) & $H_{2}=a \cdot\left(\frac{H_{1}}{a}\right)^{\mathrm{e}^{\frac{b}{(c-1) \cdot T_{2}^{(c-1)}}} \cdot-\frac{b}{(c-1) \cdot T_{1}^{(c-1)}}}$ \\
\hline
\end{tabular}

$H_{i}$ is dominant height (m) at age $T_{i}$ (years); $a, b$ and $c$ are fitted parameters of the function.

differential equations proposed by Clutter-Lenhart [20] (Model 6), Amateis-Burkhart [3] (Model 7) and Sloboda [45] (Model 8). Finally, the last group (Tab. IVc) is compound by Model 9, proposed by Cieszewski and Bella [18] applying the GADA in the height-age equation of Hossfeld IV (cited by Peschel [40]), and Models 10 to 16. These models are equations presented by Cieszewski [16] applying the GADA in the base equations of Chapman-Richards [41] (Model 10), Weibull [50] (cited by Yang et al. [51]) (Model 11), Bailey [4] (Model 12), logistic function (cited by Robertson [42]) (Model 13), Schumacher [44] (Model 14), Gompertz function (cited by Medawar [36]) (Model 15) and Log-logistic function (cited by Monserud [37]) (Model 16). All these base equations can be formulated as the basic model (Eq. (1)) with different definitions of $t$ (Tab. IVc).

$$
H=\mathrm{e}^{m} \cdot t^{b}
$$

where $H$ is the height; $t$ depends on the age (T) with different definitions (Models 10 to 16); and $m$ and $b$ are model parameters. For GADA derivation, the basic model is expanded assuming that $H$ depends on an unobservable variable $X$. In this work the models were calculated applying the simplest assumption proposed by Cieszewski [16] which is that both parameters $(m$ and $b)$ are linear functions of $X$ :

$$
\begin{aligned}
m & =m 1+m 2 \cdot X \\
b & =b 1+b 2 \cdot X
\end{aligned}
$$

and considering that $m 1=0$ and $m 2=1$. With this assumption the basic equation (Eq. (1)) results in the generalized algebraic difference equation (Eq. (4)), that is solved for $X$ with initial condition values for $H$ and $t$ (Eq. (5)) (Tab. IVc):

$$
\begin{gathered}
H_{2}=\mathrm{e}^{X} \cdot t_{2}^{(b 1+b 2 X)} \\
X=-\frac{-\ln H_{1}+b 1 \cdot \ln t_{1}}{1+b 2 \cdot \ln t_{1}} .
\end{gathered}
$$

\subsection{Data structure and model fitting}

To fit an algebraic difference equation expressed in the general form of $H_{2}=f\left(H_{1}, T_{1}, T_{2}\right)$, different data structures defined in Borders et al. [8] can be used. These data structures are relevant in any increment-based modelling. Strub [46] studied the difference between the base-age invariant stochastic regression approach (BAI) and the method of all possible prediction intervals (BAA), and the BAI approach provides better results. Anyway, the data chosen for 
Table IV. Continued. (c) Models from GADA.

\begin{tabular}{|c|c|c|}
\hline Name & Model & Generalized Algebraic difference model \\
\hline Cieszewski and Bella (1989) & (9) & $\begin{array}{l}H_{2}=\frac{H_{1}+d+r}{2+\left(\frac{4 d}{T_{2}^{c} \cdot\left(H_{1}-d+r\right)}\right)} \\
\text { with } \\
d=\frac{c}{A s i^{c}} ; r=\sqrt{\left(H_{1}-d\right)^{2}+4 d \cdot H_{1} \cdot T_{1}^{-b}}\end{array}$ \\
\hline Name & Model & Definition of $t$ \\
\hline $\begin{array}{l}\text { Cieszewski (2004) based on } \\
\text { Chapman-Richards (1959) }\end{array}$ & (10) & $t_{i}=1-\mathrm{e}^{\left(-a_{1} \cdot T_{i}\right)}$ \\
\hline $\begin{array}{l}\text { Cieszewski (2004) based on } \\
\text { Weibull (1939) }\end{array}$ & (11) & $t_{i}=1-\mathrm{e}^{\left(-T_{i}^{a 2}\right)}$ \\
\hline $\begin{array}{l}\text { Cieszewski (2004) based on } \\
\text { Bailey (1980) }\end{array}$ & (12) & $t_{i}=1-\mathrm{e}^{\left(-a 1 \cdot T_{i}^{a 2}\right)}$ \\
\hline $\begin{array}{l}\text { Cieszewski (2004) based on } \\
\text { logistic model (Robertson, 1923) }\end{array}$ & (13) & $t_{i}=\frac{1}{1+\mathrm{e}^{\left(-a \cdot T_{i}\right)}}$ \\
\hline $\begin{array}{l}\text { Cieszewski (2004) based on } \\
\text { Schumacher (1939) }\end{array}$ & (14) & $t_{i}=\mathrm{e}^{\left(-\frac{1}{T_{i}}\right)}$ \\
\hline $\begin{array}{l}\text { Cieszewski (2004) based on } \\
\text { Gompertz model (Medawar, 1940) }\end{array}$ & $(15)$ & $t_{i}=\left(\mathrm{e}^{-\mathrm{e}^{\left(-a \cdot T_{i}\right)}}\right)^{b}$ \\
\hline $\begin{array}{l}\text { Cieszewski (2004) based on } \\
\text { log-logistic model (Monserud, 1984) }\end{array}$ & (16) & $t_{i}=\frac{1}{1+\mathrm{e}^{\left(-a \cdot \ln T_{i}\right)}}$ \\
\hline
\end{tabular}

$T_{i}$ is age $\mathrm{i}$ (years); $t i$ is the definition of $T_{i}$ defined by differents authors; $A s i=$ is an age used to reduce the mean square errror (60 years in this case); $a$ and $b$ are fitted parameters of the function.

fitting the different functions comprised all the possible combinations of height-total age pairs for a tree (all possible growth intervals) $[8,9,28-30]$ because of this approach is much easier than the other method.

Functions were fitted independently to data from each stratum. The fittings were carried out using the PROC NLIN procedure on the SAS/STAT software [32]. The Marquart iterative method was selected because it is the most useful when the parameter estimates are highly correlated [27]. Additionally, it is believed that the Marquart method sometimes works when the default method (Gauss-Newton) does not. Different initial values for the model parameters were provided for the fits to avoid local least squares solutions.

The autocorrelation derived from using stem analysis data was prevented by applying the Goelz and Burk [29] correction. First, each function is fitted following ordinary non-linear least squares regression and the error term $e_{i j}$, residual from estimating $H_{\mathrm{i}}$ using $H_{\mathrm{j}}$, is expanded following an autoregressive process:

$$
e_{i j}=\rho \cdot \varepsilon_{i-1, j}+\gamma \cdot \varepsilon_{i, j-1}+\varepsilon_{i j}
$$

where: $\rho=$ autocorrelation between the current residual and the residual from estimating $H_{i-1}$ using $H_{j}$ as a predictor variable; $\gamma=$ relationship between the current residual and the residual form estimating $H_{i}$ using $H_{j-1}$ as a predictor variable; $\varepsilon_{i, j}=$ independent errors with mean zero and constant variance $\eta^{2}$. The model parameters are then obtained by fitting the expanded function. The autocorrelation parameters vary the weight of each observation by reducing the residual proportional to a previous residual. Besides, in view of the fact that the measurements are irregularly spaced, the correlations are corrected raising $\rho$ and $\gamma$ to the power of the differences between the uneven intervals $\left|t_{j}-t_{i}\right|$ [52]. Neither of the autoregressive parameters $\rho$ nor $\gamma$ are used for field applications of equations because the errors $\varepsilon_{i-1, j}$ and $\varepsilon_{i, j-1}$ cannot be observed without stem analysis [37]. Nev- ertheless, this correction only affects parameter variance estimation, so the shape of the curves does not depend on it.

\subsection{Model selection criteria}

A three-step procedure was used to evaluate and select the most appropriate model, which included qualitative as well as quantitative examinations. The first step was to evaluate the model fitting statistics based on nine model performance evaluation criteria described by Amaro et al. [2] (Tab. V), selecting those equations which appeared to be the best.

In step two, the characterisation of the model error was analysed, based on an independent data set testing. The actual height values from the testing data set were compared to the predicted height values from the previous sixteen models fitted for each stratum. For the purposes of the comparison, evaluation criteria applied in the first phase modelling were also calculated. The analysis procedure was repeated at non-descending growth intervals due to the fact that, in general, most of the current stands are in their early stages, so height estimates will be calculated at a later stage. Therefore, the compensation which can occur between predictions at decreasing and increasing growth intervals is avoided.

The correctness of the theoretical and biological aspects of the sixteen models was assessed in step 3 . This was done interactively with steps 1 and 2 . The following biological aspects were examined: (1) Signs and values of the coefficients in the model components, especially the asymptotes; (2) Quality of extrapolation outside the range of the site indexes of the modelling data as well as outside the age range; and (3) Height curve development at young ages. 
Table V. Model performance evaluation criteria (estimation and testing procedures).

\begin{tabular}{lccc}
\hline Performance criterion & Symbol & Formula* & Ideal \\
\hline Mean residual & Mres & $\sum_{i=1}^{n} \frac{e s t_{i}-o b s_{i}}{n}$ & 0 \\
Variance ratio & VR & $\frac{\sum_{i=1}^{n}\left(e s t_{i}-\overline{e s t}\right)^{2}}{\sum_{i=1}^{n}\left(o b s_{i}-\overline{o b s}\right)^{2}}$ & 1 \\
Residual mean of squares & RMS & $\frac{\sum_{i=1}\left(e s t_{i}-o b s_{i}\right)^{2}}{n-p}$ & 0 \\
Absolute mean residual & Amres & $\sum_{i=1}^{n} \frac{\left|e s t_{i}-o b s_{i}\right|}{n}$ & 0 \\
Coefficient of determination / model efficiency & $R^{2} / \mathrm{Mef}$ & $1-\frac{\sum_{i=1}^{n}\left(e s t_{i}-o b s_{i}\right)^{2}}{\sum_{i=1}^{n}\left(o b s_{i}-\overline{o b s}\right)^{2}}$ & 1 \\
Linear regression & $\alpha, \beta \mathrm{y} R_{a d j}^{2}$ & $o b s_{i}=\alpha+\beta e s t_{i}+\varepsilon_{i}$ & $\alpha=0, \beta=1, R_{a d j}^{2}=1$ \\
\hline
\end{tabular}

*est $t_{i}$ : ith estimated value; $o b s_{i}$ : ith observed value; $n$ : number of observations; $p$ : number of parameters of the model.

\subsection{Comparison of height growth models among stratums}

Once the best function had been selected, the differences in the dominant height growth models for the different stratums were compared using both the full and the reduced models. The full model corresponds to completely different sets of parameters for different stratums and is obtained by expanding each parameter, including an associated parameter as well as a dummy variable to differentiate the stratums. The reduced model corresponds to the same set of parameters for all the stratums combined.

Two tests for detecting simultaneous homogeneity among parameters were used: the Bates and Watts non-linear extra sum of squares $F$ test $[30,31]$ and the test proposed by Lakkis and Jones, in Khattree and Naik [33], to compare the differences in site index models between stratums. These tests are frequently applied to analyse differences among different geographic regions $[1,9,31]$.

Besides the full and reduced models, the sum of squares error $(S S)$ is necessary to calculate both tests. This kind of error was calculated as follows:

$$
S S=\sum_{j=1}^{m} \frac{\sum_{i=1}^{n}\left(e s t_{i}-o b s_{i}\right)^{2}}{n}
$$

where: $n=$ number of observations for each tree; $m=$ total number of trees.

The $F$-test is effected using the following equation:

$$
F=\frac{\left(\frac{S S_{r}-S S_{f}}{d f_{r}-d f_{f}}\right)}{\left(\frac{S S_{f}}{d f_{f}}\right)}
$$

where: $S S_{f}$ and $S S_{r}=$ error sum of squares for full and reduced model respectively; $d f_{r}$ and $d f_{r}=$ degrees of freedom for full and reduced model respectively. $F$ follows an $F$-distribution.

The $L$ statistic used in the Lakkis-Jones test is defined as:

$$
L=\left(\frac{S S_{f}}{S S_{r}}\right)^{m / 2}
$$

where: $S S_{f}$ and $S S_{r}=$ error sum of squares for full model and reduced model respectively; and $m=$ total number of trees. If homogeneity exists among the model vectors of parameters $\beta$, the distribution of the statistic $-2 \cdot \ln (L)$ converges in probability to a Pearson $\chi^{2}$ distribution, with $v$ degrees of freedom, where $v$ is equal to the difference between the number of parameters estimated in the full model and the reduced models.

The testing data set was checked with the group models and the evaluation criteria were also applied.

Finally, the studies of error were analysed. The data set was divided into six twenty-year interval classes, firstly according to predictor age and secondly to the absolute value of the interval of prediction $\left|T_{j}-T_{i}\right|$ [9]. This study of errors was calculated for full and reduced models.

\section{RESULTS}

The models with the best performance results in all stratums have been shown in Table VI. As good results were obtained with traditional and generalise algebraic difference approaches, the best two in each model group are presented: (a) ADA derived from height-age equations, Lundqvist-korf equation with the $b$ as free parameter (M3) and McDill-Amateis model (M5), (b) ADA derived from differential equations, Clutter-Lenhart equation (M6) and Sloboda equation (M8), (c) GADA, the Cieszewski model based on Weibull equation (M11) and based on the Bailey equation (M12). Differences among functions were very small, although the analysis of the fit statistics revealed that GADA functions generally result in slightly lower values for Mres, RMS and Amres as well as higher efficiencies. All the parameter estimates for all the functions were significant at a $\alpha$ level of 5\%. The shape of the curves is independent of the autocorrelation correction (Fig. 2 shows both fits of M12), showing practically the same curve.

The functions M11 and M12 adjusted for each stratum were again those which performed better with the testing data (Tab. VII). When all possible intervals were used, both models showed a lack of significant bias at a significant level of $0.1 \%$, except the models obtained for stratum 3 and M12 in stratum 1 . Also, the model efficiency always exceeded 0.87 and the $R^{2}$ linear regression was higher than $88 \%$. Although the results were worse for the non-descending growth interval than for the all growth interval testing, the best models performed similarly. In these cases, the model efficiencies decreased until values of up to 0.79 and bias were non significant except both models in stratum 3 . 
Table VI. Fit statistics and summary of results for the two best functions from each model group per stratum.

\begin{tabular}{|c|c|c|c|c|c|c|c|c|c|c|}
\hline \multirow[t]{2}{*}{ Stratum } & \multirow{2}{*}{$\begin{array}{l}\text { Model } \\
\text { group }\end{array}$} & \multirow{2}{*}{$\begin{array}{l}\text { No. } \\
\text { model }\end{array}$} & \multirow[t]{2}{*}{ Mres } & \multirow[t]{2}{*}{ VR } & \multirow[t]{2}{*}{ RMS } & \multirow[t]{2}{*}{ Amres } & \multirow[t]{2}{*}{ Mef } & \multicolumn{3}{|c|}{ Linear regression } \\
\hline & & & & & & & & $\bar{a}$ & $b$ & $R^{2}$ \\
\hline \multirow{6}{*}{1} & \multirow{2}{*}{$\mathrm{a}$} & 3 & $-0.0142^{1}$ & 1.0014 & 0.1887 & 0.3074 & 0.9854 & 0.0463 & 0.9913 & 0.9855 \\
\hline & & 5 & $-0.0124^{1}$ & 1.0025 & 0.1845 & 0.3060 & 0.9857 & 0.0508 & 0.9909 & 0.9858 \\
\hline & \multirow{2}{*}{$\mathrm{b}$} & 6 & $-0.0022^{1}$ & 0.9998 & 0.1959 & 0.3103 & 0.9849 & 0.0547 & 0.9918 & 0.9849 \\
\hline & & 8 & $-0.0105^{1}$ & 0.9998 & 0.1843 & 0.3060 & 0.9858 & 0.0434 & 0.9922 & 0.9858 \\
\hline & \multirow{2}{*}{$\mathrm{c}$} & 11 & $-0.0082^{1}$ & 0.9992 & 0.1785 & 0.2995 & 0.9862 & 0.0420 & 0.9928 & 0.9862 \\
\hline & & 12 & $-0.0095^{1}$ & 0.9994 & 0.1807 & 0.3024 & 0.9860 & 0.0421 & 0.9926 & 0.9861 \\
\hline \multirow{6}{*}{2} & \multirow{2}{*}{$\mathrm{a}$} & 3 & $-0.0015^{1}$ & 0.9898 & 0.2617 & 0.3419 & 0.9787 & 0.0383 & 0.9938 & 0.9787 \\
\hline & & 5 & $0.0014^{1}$ & 0.9905 & 0.2562 & 0.3369 & 0.9792 & 0.0422 & 0.9936 & 0.9792 \\
\hline & \multirow{2}{*}{$\mathrm{b}$} & 6 & $0.0033^{1}$ & 0.9903 & 0.2816 & 0.3719 & 0.9771 & 0.0502 & 0.9927 & 0.9771 \\
\hline & & 8 & $-0.0038^{1}$ & 0.9924 & 0.2606 & 0.3427 & 0.9788 & 0.0443 & 0.9925 & 0.9788 \\
\hline & \multirow{2}{*}{$\mathrm{c}$} & 11 & $-0.0018^{1}$ & 0.9910 & 0.2536 & 0.3397 & 0.9794 & 0.0397 & 0.9935 & 0.9794 \\
\hline & & 12 & $0.0026^{1}$ & 0.9882 & 0.2381 & 0.3311 & 0.9806 & 0.0310 & 0.9955 & 0.9806 \\
\hline \multirow{6}{*}{3} & \multirow{2}{*}{$\mathrm{a}$} & 3 & $-0.0031^{1}$ & 0.9947 & 0.2303 & 0.3208 & 0.9831 & 0.0384 & 0.9939 & 0.9832 \\
\hline & & 5 & $-0.0014^{1}$ & 0.9961 & 0.2352 & 0.3270 & 0.9828 & 0.0459 & 0.9931 & 0.9828 \\
\hline & \multirow{2}{*}{$\mathrm{b}$} & 6 & $0.0099^{1}$ & 0.9925 & 0.2680 & 0.3465 & 0.9804 & 0.0532 & 0.9937 & 0.9804 \\
\hline & & 8 & $-0.0033^{1}$ & 0.9953 & 0.2299 & 0.3214 & 0.9832 & 0.0399 & 0.9937 & 0.9832 \\
\hline & \multirow{2}{*}{$\mathrm{c}$} & 11 & $-0.0018^{1}$ & 0.9949 & 0.2279 & 0.3203 & 0.9833 & 0.0398 & 0.9939 & 0.9833 \\
\hline & & 12 & $-0.0023^{1}$ & 0.9943 & 0.2272 & 0.3199 & 0.9834 & 0.0370 & 0.9943 & 0.9834 \\
\hline \multirow{6}{*}{4} & \multirow{2}{*}{$\mathrm{a}$} & 3 & $-0.0009^{1}$ & 0.9911 & 0.2794 & 0.3662 & 0.9767 & 0.0528 & 0.9916 & 0.9768 \\
\hline & & 5 & $0.0030^{1}$ & 0.9946 & 0.2682 & 0.3624 & 0.9777 & 0.0647 & 0.9904 & 0.9777 \\
\hline & \multirow{2}{*}{$\mathrm{b}$} & 6 & $0.0182^{1}$ & 0.9895 & 0.3540 & 0.4146 & 0.9705 & 0.0867 & 0.9893 & 0.9706 \\
\hline & & 8 & $-0.0069^{1}$ & 0.9951 & 0.2770 & 0.3644 & 0.9769 & 0.0587 & 0.9898 & 0.9770 \\
\hline & \multirow{2}{*}{$\mathrm{c}$} & 11 & $-0.0043^{1}$ & 0.9933 & 0.2699 & 0.3615 & 0.9775 & 0.0536 & 0.9910 & 0.9776 \\
\hline & & 12 & $0.0055^{1}$ & 0.9922 & 0.2463 & 0.3514 & 0.9795 & 0.0536 & 0.9925 & 0.9795 \\
\hline
\end{tabular}

Only the two best functions from each group are presented; ${ }^{1}$ Non significant with $P>0.05$.

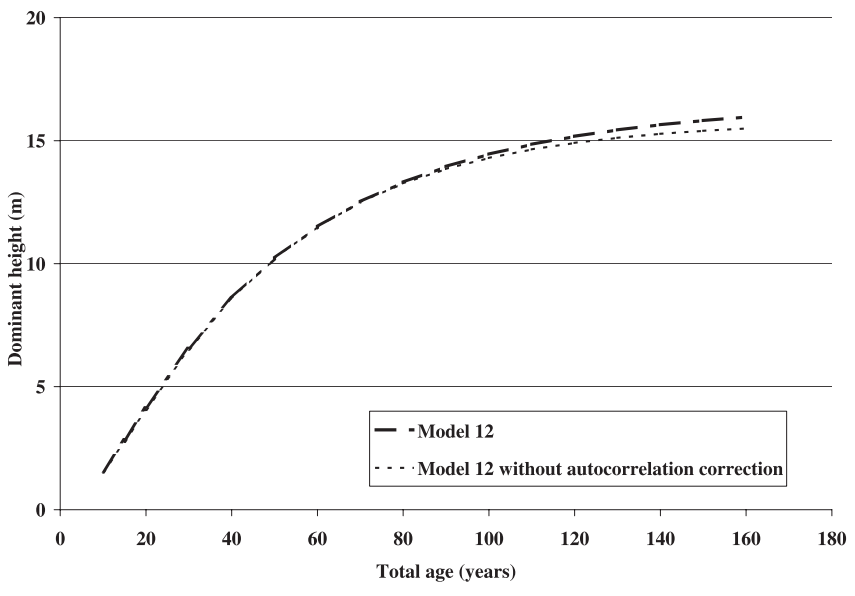

Figure 2. Shapes of the curves of Model 12 resulting from both autocorrelation correction and not autocorrelation correction fits.

All the curves assume biologically reasonable shapes, which prevent unrealistic height predictions when extrapolating the function beyond the range of the original data. The gen- eralized algebraic difference form of Cieszewski model based on Bailey was selected (M12) based in the good results in the performance criteria define in Table $\mathrm{V}$ with both fitting and testing data, results in the characterisation of the model error and the correctness of the theoretical and biological aspects, although the differences in the adjustment and testing were very similar that the other functions presented in Table VI.

Assuming the suitability of the model M12, it is necessary to analyse the dominant height growth pattern among stratums. Figure 3 represents the model M12 adjusted for each stratum and forced to pass through age-height pairs $(60,7),(60,10)$, $(60,13)$ and $(60,16)$. Stratums 1 and 3 seem to show a similar dominant height growth pattern, whereas stratums 2 and 4 appear to be a bit of different than previous stratums. On the other hand, stratum 1 works different way for younger ages.

The non-linear extra sum of squares $F$ test and the LakkisJones test revealed that, the null hypothesis of parameter homogeneity was acceptable in all the reduced models tested except model with stratum 2 and 3 together (Tab. VIII). On the other hand, the fit statistics obtained with full and reduced models, in all stratums group and 2 and 3 stratums group, were 
Table VII. Fit statistics and summary of results for the testing data set for the best functions (Models 11 and 12).

\begin{tabular}{|c|c|c|c|c|c|c|c|c|c|}
\hline \multirow{2}{*}{ Str. } & \multirow{2}{*}{ Model } & \multirow{2}{*}{ Mres } & \multirow{2}{*}{ VR } & \multirow{2}{*}{ RMS } & \multirow{2}{*}{ Amres } & \multirow{2}{*}{ Mef } & \multicolumn{3}{|c|}{ Linear regression } \\
\hline & & & & & & & $\bar{a}$ & $b$ & $R^{2}$ \\
\hline \multicolumn{10}{|c|}{ All possible intervals } \\
\hline \multirow{2}{*}{1} & 11 & $-0.0581^{3}$ & 1.0169 & 1.0013 & 0.7122 & 0.8808 & 0.2972 & 0.9333 & 0.8858 \\
\hline & 12 & -0.0644 & 1.0155 & 1.0379 & 0.7266 & 0.8765 & 0.2992 & 0.9318 & 0.8817 \\
\hline \multirow{2}{*}{2} & 11 & $-0.0233^{1}$ & 0.9778 & 0.9165 & 0.6830 & 0.8909 & 0.2116 & 0.9556 & 0.8929 \\
\hline & 12 & $-0.0166^{1}$ & 1.0267 & 0.9640 & 0.7097 & 0.8853 & 0.3474 & 0.9311 & 0.8902 \\
\hline \multirow{2}{*}{3} & 11 & -0.0814 & 1.1076 & 0.9943 & 0.6960 & 0.8816 & 0.4622 & 0.8984 & 0.8939 \\
\hline & 12 & -0.0749 & 1.1073 & 0.9832 & 0.6933 & 0.8830 & 0.4646 & 0.8990 & 0.8949 \\
\hline \multirow{2}{*}{4} & 11 & $-0.0214^{1}$ & 0.9811 & 0.9107 & 0.6813 & 0.8916 & 0.2198 & 0.9544 & 0.8937 \\
\hline & 12 & $-0.0225^{1}$ & 1.0321 & 0.9640 & 0.7085 & 0.8853 & 0.3537 & 0.9289 & 0.8905 \\
\hline \multicolumn{10}{|c|}{ Non-descending intervals } \\
\hline \multirow{2}{*}{1} & 11 & $-0.0423^{1}$ & 0.8582 & 1.3928 & 0.8580 & 0.8034 & 0.1812 & 0.9682 & 0.8045 \\
\hline & 12 & $-0.0474^{1}$ & 0.8345 & 1.4454 & 0.8767 & 0.7959 & 0.1136 & 0.9771 & 0.7967 \\
\hline \multirow{2}{*}{2} & 11 & $0.0759^{3}$ & 0.9098 & 1.2920 & 0.8282 & 0.8176 & 0.4230 & 0.9498 & 0.8207 \\
\hline & 12 & $0.0490^{1}$ & 1.0821 & 1.3835 & 0.8640 & 0.8047 & 0.9373 & 0.8720 & 0.8227 \\
\hline \multirow{2}{*}{3} & 11 & -0.1991 & 1.0132 & 1.4878 & 0.8704 & 0.7900 & 0.5728 & 0.8926 & 0.8073 \\
\hline & 12 & -0.1846 & 1.0379 & 1.4673 & 0.8653 & 0.7928 & 0.6455 & 0.8843 & 0.8116 \\
\hline \multirow{2}{*}{4} & 11 & $0.0767^{3}$ & 0.9281 & 1.2857 & 0.8261 & 0.8185 & 0.4817 & 0.9414 & 0.8225 \\
\hline & 12 & $0.0268^{1}$ & 1.0674 & 1.3717 & 0.8582 & 0.8063 & 0.8777 & 0.8777 & 0.8224 \\
\hline
\end{tabular}

Only the functions 11 and 12 are presented; ${ }^{1}$ Non significant with $P>0.05 ;{ }^{2}$ Non significant with $0.05>P>0.01 ;{ }^{3}$ Non significant with $0.01>P>0.001$.

Table VIII. $L$ and $F$ statistics.

\begin{tabular}{lccccll}
\hline MODEL & $D f$ full model & $S S f$ & $D f$ reduced model & $S S r$ & $\begin{array}{l}\text { Parameter } \\
L\end{array}$ & $\begin{array}{l}\text { Parameter } \\
F\end{array}$ \\
\hline All stratums & 135 & 37.6403 & 144 & 38.6613 & 0.1399 & 0.4069 \\
2,3 and 4 & 116 & 33.5529 & 122 & 34.7668 & 0.1085 & 0.6994 \\
1,2 and 4 & 62 & 18.0334 & 68 & 18.5457 & 0.3699 & 0.2935 \\
1,3 and 4 & 106 & 28.0137 & 112 & 28.4247 & 0.4328 & 0.2592 \\
1,2 and 3 & 121 & 33.4846 & 127 & 33.9647 & 0.3964 & 0.2892 \\
1 and 2 & 48 & 13.8231 & 51 & 13.9970 & 0.7135 & 0.2013 \\
1 and 3 & 92 & 23.5817 & 95 & 23.8034 & 0.6322 & 0.2883 \\
2 and 3 & 102 & 29.3426 & 105 & 30.9434 & $0.0568^{*}$ & $1.8549^{*}$ \\
1 and 4 & 33 & 8.3522 & 36 & 8.8404 & 0.3303 & 0.6430 \\
2 and 4 & 43 & 13.8915 & 46 & 14.1246 & 0.6651 & 0.2406 \\
3 and 4 & 87 & 23.8718 & 90 & 24.4965 & 0.3008 & 0.7590 \\
\hline
\end{tabular}

Significant $L$-values and $F$-values are marked with ${ }^{*}$.

very similar (Tab. IX). According to these results, the total reduced model (all stratums together) can be selected. This model was checked using the all possible intervals (3082 data), testing data set, resulting in a mean error $(-0.0522 \mathrm{~m})$ not significantly different from zero at a significance level of $0.1 \%$ and an efficiency of 0.89 . The results for the non-descending growth intervals (1541 data) were $-0.0782 \mathrm{~m}$ at $0.1 \%$ and an efficiency of 0.81 . These values are very similar to those obtained when applying the function M12 adjusted for each stratum to the testing data set (Tab. VII).
The different distribution of the error according to predictor age and prediction interval length are shown in Tables $\mathrm{X}$ and XI for the total full model (one model for each stratum) and the total reduced model (all stratums together). Except for predictor age between $60-80$ years, the mean errors were non significant at a significant level of $1 \%$. In the case of prediction interval length, the model was unbiased for medium and large intervals ( $>40$ years) at a significant level of 5\%. For short prediction intervals ( $0-40$ years) the mean error was non significant different from zero at a significant level of $0.1 \%$ 
Table IX. Fit statistics of the full and reduced models for grouped stratums.

\begin{tabular}{|c|c|c|c|c|c|c|c|c|c|c|}
\hline \multirow{2}{*}{ Stratum group } & \multirow{2}{*}{$N$} & \multirow{2}{*}{ Model } & \multirow{2}{*}{ Mres } & \multirow{2}{*}{ VR } & \multirow{2}{*}{ RMS } & \multirow{2}{*}{ Amres } & \multirow{2}{*}{ Mef } & \multicolumn{3}{|c|}{ Linear regression } \\
\hline & & & & & & & & $a$ & $b$ & $R^{2}$ \\
\hline \multirow{2}{*}{ All stratums } & \multirow{2}{*}{14492} & $\mathrm{~F}$ & $0.0019^{1}$ & 0.9950 & 0.2228 & 0.3222 & 0.9830 & 0.0388 & 0.994 & 0.9831 \\
\hline & & $\mathrm{R}$ & $0.0035^{1}$ & 0.9955 & 0.2309 & 0.3274 & 0.9824 & 0.0408 & 0.9934 & 0.9825 \\
\hline \multirow{2}{*}{2 and 3} & \multirow{2}{*}{10410} & $\mathrm{~F}$ & $0.0010^{1}$ & 0.9936 & 0.2299 & 0.3227 & 0.9828 & 0.0357 & 0.9945 & 0.9828 \\
\hline & & $\mathrm{R}$ & $0.0055^{1}$ & 0.9962 & 0.2443 & 0.3285 & 0.9817 & 0.0436 & 0.9927 & 0.9817 \\
\hline
\end{tabular}

${ }^{1}$ Not significant with $P>0.05$; F: Full model; R: Reduced model.

Table X. Mean absolute error analysis. Distribution by predictor age classes.

\begin{tabular}{llccccccc}
\hline \multicolumn{1}{c}{ Predictor age class } & & Total & $0-20$ & $20-40$ & $40-60$ & $60-80$ & $80-100$ & $>100$ \\
\hline$n$ & & 14492 & 4532 & 5756 & 2740 & 1054 & 321 & 90 \\
Stratum group & Model & Error & Error & Error & Error & Error & Error & Error \\
\multirow{2}{*}{ All stratums } & $\mathrm{F}$ & $0.0019^{1}$ & $0.0003^{1}$ & $0.0106^{1}$ & $0.0143^{1}$ & -0.0613 & $-0.0359^{1}$ & $0.0143^{1}$ \\
& $\mathrm{R}$ & $0.0035^{1}$ & $-0.0006^{1}$ & $0.0122^{2}$ & $0.0144^{1}$ & $-0.0459^{3}$ & $-0.0146^{1}$ & $-0.0523^{1}$ \\
\hline
\end{tabular}

${ }^{1}$ Not significant with $P>0.05 ;{ }^{2}$ not significant with $0.05>P>0.01 ;{ }^{3}$ not significant with $0.01>P>0.001 ; n=$ data number; error $=$ $\sum\left(H_{2 \text { pre }}-H_{2 \text { obs }}\right) / n$.

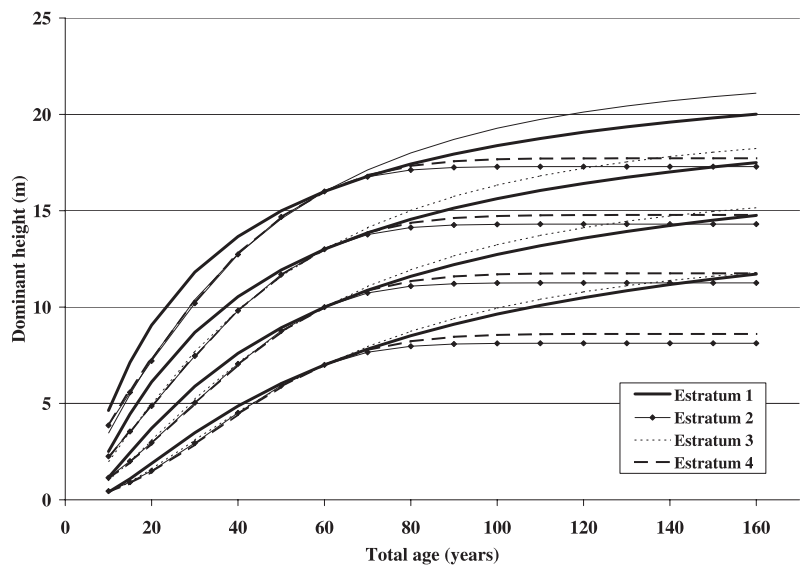

Figure 3. Stratum site index curves for Quercus pyrenaica Willd. in Center-West Spain using the Bailey function (Model 12).

except reduced model for prediction interval of 20-40. For all predictor age classes and prediction interval classes the mean errors were similar for full and reduced models.

The mathematical expression of the selected site index model for $Q$. pyrenaica in northwest Spain is the following:

$$
\begin{aligned}
H_{2} & =\mathrm{e}^{X} \cdot t_{2}^{(15.172(0.7607)-4.2126(0.2127) \cdot X)} \\
X & =-\frac{-\ln H_{1}+15.172(0.7607) \cdot \ln t_{1}}{1-4.2126(0.2127) \cdot \ln t_{1}} \\
t_{i} & =1-\mathrm{e}^{\left(-0.1439(0.0112) \cdot T_{i}^{0.6711(0.0164)}\right)}
\end{aligned}
$$

where $H_{i}$ is dominant height (m) for the stand at age $T_{i}$ (years) and error standard of parameters are in brackets.

As regards reference age, that of 60 years was selected based on ages that are intermediate would be best simply be-

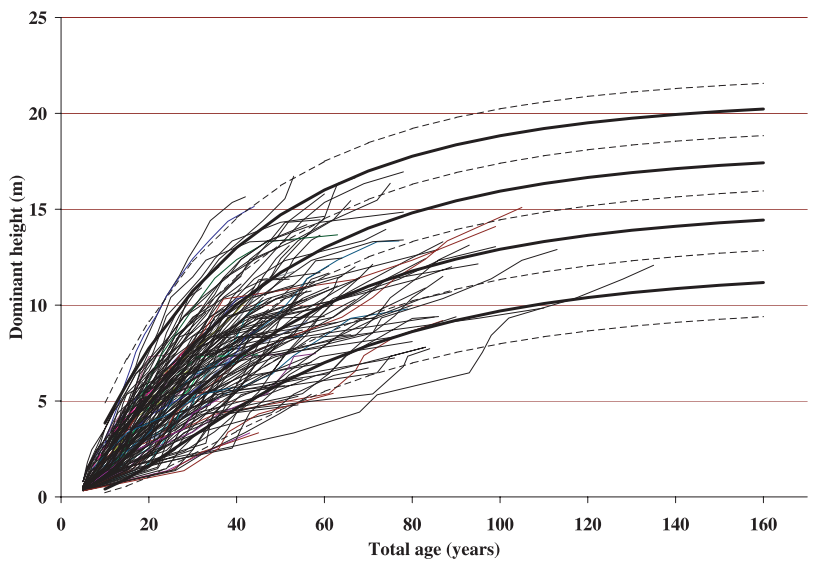

Figure 4. Site index curves for Quercus pyrenaica Willd. in northwest Spain using the Bailey function together with the stem analysis.

cause extreme ages would poorly predict height at opposite extreme of age [29], and corresponds to the greatest age with a not significant error. Over 60 years, the absolute mean error increases and the number of sample trees decreases, with only four trees over 100 years and nineteen over 80 years. The site index curves for $Q$. pyrenaica Willd. in northwest Spain, forced to pass through the points $(60,16),(60,13),(60,10)$ and $(60,7)$, are shown in Figure 4. As shown in Figure 5, the estimated site indices of the plots are distributed evenly between stratums.

\section{DISCUSSIONS AND CONCLUSIONS}

This study presents a site index model for the $Q$. pyrenaica stands in northwest Spain. The generalised algebraic difference approach (GADA) used to derive dynamic height 
Table XI. Mean absolute error analysis. Distribution by prediction interval length classes |Tj-Ti|.

\begin{tabular}{llccccccc}
\hline Predictor interval class & & Total & $0-20$ & $20-40$ & $40-60$ & $60-80$ & $80-100$ & $>100$ \\
\hline$n$ & & 14492 & 9128 & 3772 & 1168 & 368 & 56 & 8 \\
Stratum group & Model & Error & Error & Error & Error & Error & Error & Error \\
\multirow{2}{*}{ All stratums } & $\mathrm{F}$ & $0.0019^{1}$ & $-0.008^{2}$ & $0.0287^{3}$ & $0.0034^{1}$ & $-0.0328^{1}$ & $-0.0164^{1}$ & $-0.026^{1}$ \\
& $\mathrm{R}$ & $0.0035^{1}$ & $-0.008^{2}$ & 0.0318 & $0.0154^{1}$ & $-0.0372^{1}$ & $-0.0212^{1}$ & $0.0011^{1}$ \\
\hline
\end{tabular}

${ }^{1}$ Not significant with $P>0.05 ;{ }^{2}$ not significant with $0.05>P>0.01 ;{ }^{3}$ not significant with $0.01>P>0.001 ; n=$ data number; error $=$ $\sum\left(H_{2 \text { pre }}-H_{2 \mathrm{obs}}\right) / n$.

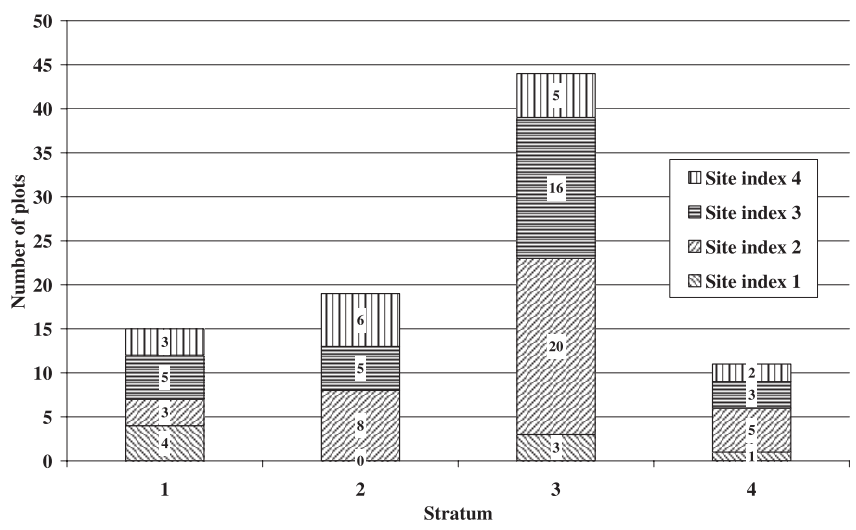

Figure 5. Distribution of plots by site indices and stratums.

functions of dominant trees resulted in slightly better fits than the traditional algebraic difference approach (ADA). GADA is more parsimonious than most traditional approaches (fixedbase-age equations), it can derive more complex equations than ADA and it assures a high degree of robustness in applications [17]. The main advantage of GADA is that it allows polymorphic curves with multiple asymptotes, while model derived with ADA are either anamorphic or have single asymptotes [17]. The small differences obtained among both approaches were probably due to the few available data of old ages, showing good results with polymorphic models with single asymptote.

According to fit statistics, the generalized algebraic difference form of the growth function of Cieszewski [16] based on Bailey equation [4] (M12) was chosen to explain the height growth pattern of this species. The statistic criteria with testing data did not fall in value, and the generalized algebraic difference form of the growth function of Cieszewski based on Bailey equation was still the best pattern. Testing using nondescending intervals produced worse results that working with all possible intervals, so it seemed advisable to analyse different data structures, especially in the testing phase since the use of descending intervals is not very common in site index estimation.

Comparing the results of selected model (M12) among stratums, there were some differences in error measurements and model efficiency values. In the same way, parameter estimates vary considerably among stratums, especially asymptote estimates. Nevertheless, as it has been mentioned, there is little data available for an adequate asymptote estimation due to the absence of old stands, probably as a result of the traditional use of $Q$. pyrenaica stands for firewood and charcoal.

In spite of the apparent differences observed also in the graphical comparison of the site index curves (Fig. 3) obtained by fitting the selected function to each stratum, the statistical tests did not reject the null hypothesis of equality of height growth patterns, except to 2 and 3 stratums group (Tab. VIII). Another method for comparing stratum growth models is to examine the fit statistics for full and reduced models $[9,31]$, but no differences were found to both all stratums group and 2 and 3 stratums group (Tab. IX). In the same way, the analysis of absolute mean errors by age and prediction interval classes resulted in similar errors for total full and reduced models (Tabs. X and XI). Moreover, by employing a single site index model for all the studied area, the quality of rebollo oak coppices can be classified and decisions can be taken regarding the different silvicultural treatments that need to be carried out in each of them. At present, due to the state of abandonment and decay in which many of these stands have fallen [10,12], it is necessary to establish priority areas where resources should be invested and this site index model may provide a key tool for this purpose. A common dominant height growth model could also simplify the development of a site index model based on ecological variables. Although it is sometimes necessary to stratify the study area when looking for relationships between site index and ecological variables [22,49], the analysis is facilitated with a single dominant height growth pattern.

Modelling dominant height growth for $Q$. pyrenaica in the Mediterranean region has seldom been attempted. The site index curves proposed by Torre [48] for León province (included in the study area) present lower growth rates at old ages than the model developed in this study, whereas the curves proposed by Bengoa [7] for Rioja region (close to the study area) show similar height growth patterns (Fig. 6a), although neither model included data from old trees. If the obtained curves are compared with the site index model for Portuguese $Q$. pyrenaica stands $[12,13]$ the latter shows higher growth rates at younger ages and a larger gap between the best and the worst site qualities (Fig. 6b) with the existence of two higher qualities. It is probably due to the different climatic conditions between the natural area of distribution of the species in Portugal (Atlantic climate) and in Castilla y León (Continental climate).

We were aware of the limitations of the data we used, having measurements for only four trees over 100 years old and only nineteen over 80 years. In other species it is usually difficult to find old trees in good condition because they are 

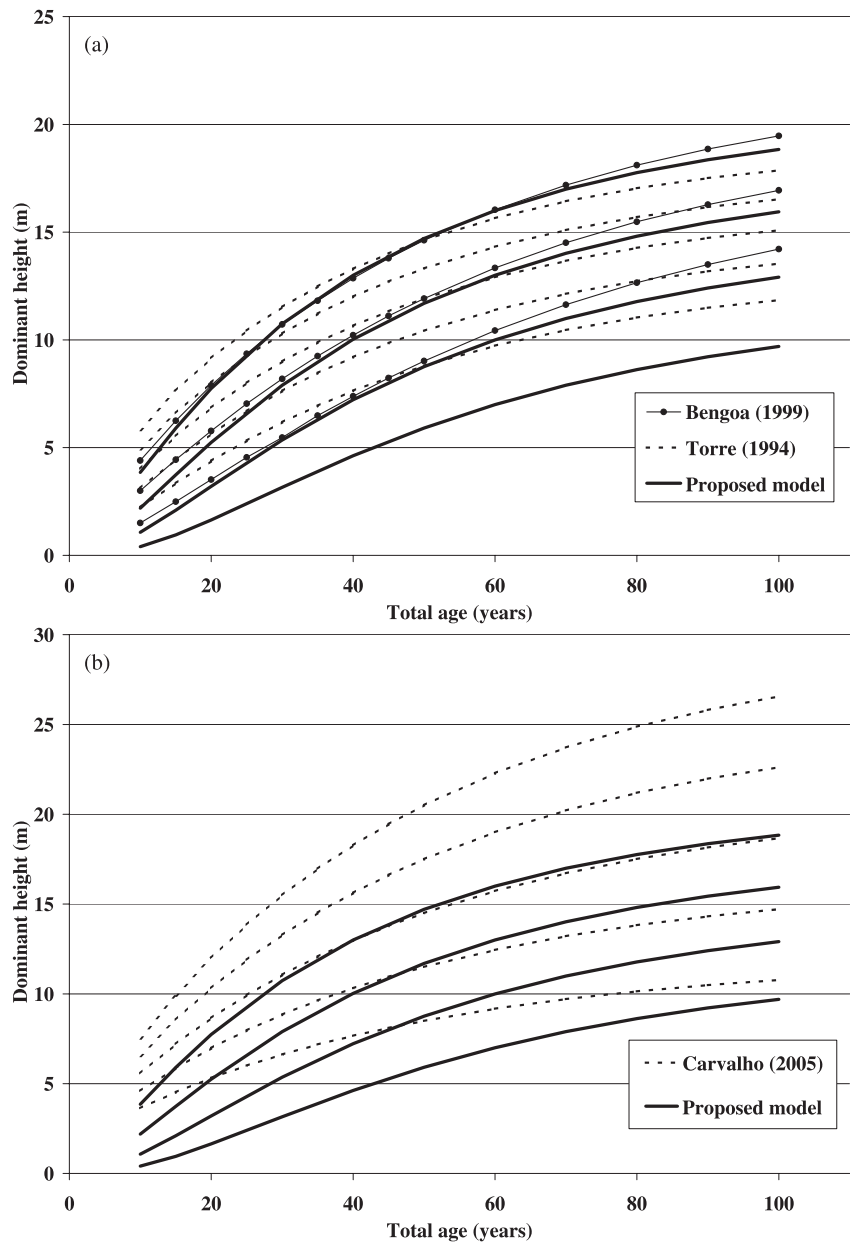

Figure 6. Site index curves for Quercus pyrenaica Willd. published in Spain (a) and Portugal (b).

felled in shorter rotation periods $[12,13,39]$. In the case of $Q$. pyrenaica,the height growth observed through stem analysis with frequent changes in site class (Fig. 7), indicates the difficulty to correctly identify a real dominant rebollo oak tree, perhaps due to the past management of these stands [10]. Clear cutting with or without standards have traditionally been applied on most $Q$. pyrenaica stands, resulting in high densities that could cause height growth stagnation in the absence of intervention [10]. The selection of standards or the management as open woodland can vary the competition relations and growth patterns of trees.

The high variability in silvicultural and ecological conditions makes difficult the use of dominant height as a site index and it would be necessary to study other possible site indices like basal area growth or diameter as well as to integrate the stand structure or typology in the analysis. In spite of these aspects which require further study, the large sampled area of this study and the good results obtained in different ecological conditions (stratums and testing data) makes this site index model a good option for classifying site qualities of $Q$. pyrenaica stands.

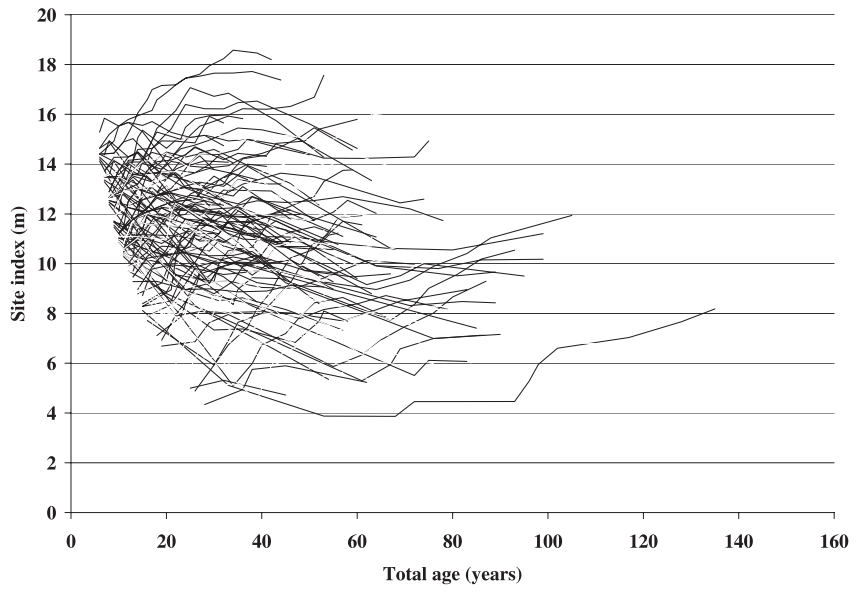

Figure 7. Site index predictions against total age using stem analysis data.

Acknowledgements: We would like to thank Dr. Oscar Cisneros González (DIEF Valonsadero, Spain) for his critical comments on the manuscript. The scholarship of P. Adame was financed by CastillaLeón government. This study was financed by the project "Estudio autoecológico y modelos de gestión de los rebollares (Quercus pyrenaica Willd.) y normas selvícolas para Pinus pinea L. y Pinus sylvestris L. en Castilla y León", collaboration agreement between INIA and Castilla-León government. We are also grateful to anonymous reviewers for their constructive comments on the manuscript.

\section{REFERENCES}

[1] Álvarez González J.G., Ruíz González A.D., Rodríguez Soalleiro R., Barrio Anta M., Ecoregional site index models for Pinus pinaster in Galicia (northwestern Spain), Ann. For. Sci. 62 (2005) $115-127$.

[2] Amaro A., Reed D., Tomé M., Themido I., Modeling dominant height growth: eucalyptus plantations in Portugal, For. Sci. 44 (1998) 37-46.

[3] Amateis R.L., Burkhart H.E., Site index curves for loblolly pine plantations on cutover-site prepared lands, South. J. Appl. For. 9 (1985) 166-169.

[4] Bailey R.L., The potential of Weibull-type functions as flexible growth curves: Discussion, Can. J. For. Res. 10 (1980) 117-118.

[5] Bailey R.L., Cieszewzki C.J., Development of a well-behaved siteindex equation: jack pine in north-central Ontario: comment, Can J. For. Res. 30 (2000) 1667-1668.

[6] Bailey R.L., Clutter J.L., Base-age invariant polymorphic site curve, For. Sci. 20 (1974) 155-159.

[7] Bengoa Martínez de Mandojana J.L., Análisis de un modelo de crecimiento en altura de masas forestales. Aplicación a la masas de Quercus pyrenaica de La Rioja, Universidad Politécnica de Madrid, Madrid, 1999, $317 \mathrm{p}$

[8] Borders B.E., Bailey R.L., Clutter M.L., Forest Growth models: parameter estimation using real growth series, in: The IUFRO Forest Growth Modeling and Predicition Conference, Minneapolis, MN, 1988, pp. 660-667.

[9] Calama R., Cañadas N., Montero G., Inter-regional variability in site index models for even-aged stands of stone pine (Pinus pinea L.) in Spain, Ann. For. Sci. 60 (2003) 259-269.

[10] Cañellas I., Del Río M., Roig S., Montero G., Growth response to thinning in Quercus pyrenaica Willd. coppice stands in Spanish central mountain, Ann. For. Sci. 61 (2004) 243-250. 
[11] Carmean W.H., Site index curves for upland oaks in the Central States, For. Sci. 18 (1972) 109-120.

[12] Carvalho J.P., dos Santos J.S., Reimao D., Gallardo J.F., Alves P.C., Grosso-Silva J.M., dos Santos T.M., Pinto M.A., Marques G., Martins L.M., Carvalheira M., Santos J., O Carvalho Negral, Programa AGRO, Medida 8.1., Vila Real, 2005.

[13] Carvalho J.P., Parresol B.R., A site model for Pyrenean oak (Quercus pyrenaica) stands using a dynamic algebraic difference equation, Can. J. For. Res. 35 (2005) 93-99.

[14] Ceballos L., Ruiz de la Torre J., Arboles y arbustos, Sección de Publicaciones de la Escuela Técnica Superior de Ingenieros de Montes, Madrid, 1979.

[15] Cieszewski C.J., Comparing fixed- and variable-base-age site equations having single versus multiple asymptotes, For. Sci. 48 (2002) $7-23$.

[16] Cieszewski C.J., GADA derivation of dynamic site equations with polymorphism and variable asymptotes form Richards, Weibull, and other exponential functions, PMRC Tecnical Report 20045, Daniel B. Warnell School of Forest Resources, University of Georgia, 2004, 16 p.

[17] Cieszewski C.J., Bailey R.L., Generalized algebraic difference approach: theory based derivation of dynamic equations with polymorphism and variable asymptotes, For. Sci. 46 (2000) 116-126.

[18] Cieszewski C.J., Bella I.E., Polymorfic height and site index curves for lodgepole pine in Alberta, Can. J. For. Res. 19 (1989) 11511160.

[19] Clutter J.L., Forston J.C., Piennar L.V., Brister G.H., Bailey L., Timber Management - A Quantitative Approach, Wiley, New York, 1983.

[20] Clutter J.L., Lenhart D.J.D., Site index curves for old-field loblolly pine plantations in Georgia Piedmont, Ga. For. Res. Counc. Rep. 22 (1968).

[21] Costa M., Morla C., Sainz H., Los Bosques Ibéricos. Una interpretación geobotánica, Ed. Planeta, 1996.

[22] Chen H.Y.H., Krestov P.V., Klinka K., Trembling aspen site index in relation to environmental measures of site quality at two spatial scales, Can. J. For. Res. 32 (2002) 112-119.

[23] DGCN, II Inventario Forestal Nacional, Ministerio de Medio Ambiente, Madrid, 1986-1996.

[24] Duplat P., Tran-Ha M., Modélisation de la croissance en hauteur dominante du chêne sessile (Quercus petraea Liebl.) en France. Variabilité inter-régionale et effet de la période récente (19591993), Ann. Sci. For. 54 (1997) 611-634.

[25] Elena Roselló R., Clasificación biogeoclimática de España Peninsular y Balear, MAPA, Madrid, 1997.

[26] Elfving B., Kiviste A., Construction of site index equations for Pinus sylvestris L. using permanent plot data in Sweden, For. Ecol. Manage. 98 (1997) 125-134.

[27] Fang Z., Bailey R.L., Height-diameter models for tropical forest on Hainan Island in southern China, For. Ecol. Manage. 110 (1998) 315-327.

[28] Furnival G.M., Gregoire T.G., Valentine H.T., An analysis of three methods for fitting site-index curves, For. Sci. 36 (1990) 464-469.

[29] Goelz J.C.G., Burk T.E., Development of a well-behaved site index equations: jack pine in north central Ontario, Can. J. For. Res. 22 (1992) 776-784.

[30] Huang S., Development of compatible height and site index models for young and mature stands within an ecosystem-based management framework, in: Empirical and process based models for forest tree and stand growth simulation, Oeiras, Portugal, 1997, pp. 61-98.
[31] Huang S., Price D., Titus S.J., Development of ecoregion-based height-diameter models for white spruce in boreal forests, For. Ecol. Manage. 129 (2000) 125-141.

[32] Inc S.I., SAS/STAT user's guide, version 8, SAS Institute Inc., Cary, NC, 2000

[33] Khattree R., Naik D.N., Applied multivariate statistics with SAS software, SAS Institute Inc., Cary, NC, 1995.

[34] Korf V., A mathematical definition of stand volume growth law, Lesnicka Prace 18 (1939) 337-339.

[35] McDill M.E., Amateis R.L., Measuring forest site quality using the parameters of a dimensionally compatible height growth function, For. Sci. 38 (1992) 409-429.

[36] Medawar P.B., Growth, growth energy, and ageing of the chicken's heart, Proc. Roy. Soc. B. 129 (1984) 332-355.

[37] Monserud R.A., Height growth and site index curves for inland Douglas-fir based on stem analysis data and forest habitat type, For. Sci. 30 (1984) 943-965.

[38] Newberry J.D., A note on Carmean's estimate of height from stem analysis data, For. Sci. 37 (1991) 368-369.

[39] Palahí M., Tomé M., Pukkala T., Trasobares A., Montero G., Site index model for Pinus sylvestris in north-east Spain, For. Ecol. Manage. 187 (2004) 35-47.

[40] Peschel W., Die mathematischen Methoden zur Herteitung der Wachstums-gesetze von Baum und Bestand und die Ergebnisse ihrer Anwendung, Thatandter Forstl. Jarb. 89 (1938) 169-274.

[41] Richards F.J., A flexible growth function for empirical use, J. Exp. Bot. 10 (1959) 290-300.

[42] Robertson T.B., The chemical basis of growth and senescence, Philadelphia and London, 1923.

[43] Sánchez-González M., Tomé M., Montero G., Modelling height and diameter growth of dominant cork oak trees in Spain, Ann. For. Sci. 62 (2005) 633-643.

[44] Schumacher F.X., A new growth curve and its application to timber yield studies, J. For. 37 (1939) 819-820.

[45] Sloboda B., Zur Darstelling von Wachstumprozessen mit Hilfe von Differentialgleichungen erster Ordung, Mitteillungen der Badenwürten-bergische Forstlichten Versuchs und Forschungsanstalt, 1971.

[46] Strub M., Base-age invariance properties of two techniques for estimating the parameters of the site models, For. Sci. (in press).

[47] Sturtevant B.R., Seagle S.W., Comparing estimates of forest site quality in old second-growth oak forests, For. Ecol. Manage. 191 (2004) 311-328.

[48] Torre Antón M., Degradación inducida por algunas prácticas agrarias tradicionales. El caso de los rebollares (Quercus pyrenaica Willd.) de la provincia de León, Universidad Politécnica de Madrid, Madrid, 1994, 246 p.

[49] Wang G.G., Klinka K., Use of sypnoptic variables in predicting white spruce site index, For. Ecol. Manage. 80 (1996) 95-105.

[50] Weibull W., A statistical theory of the strength of material, Handl, 1939.

[51] Yang R.C., Kozac A., Smith J.H.G., The potential of Weibull-type functions as flexible growth curves, Can. J. For. Res. 8 (1978) 424431.

[52] Zimmerman L., Núñez-Anton V., Parametric modelling of growth curve data: An overview, Soc. Estad. Invest. Oper. 10 (2001) 1-73. 